\title{
PEMBERIAN DUKUNGAN PSIKOSOSIAL PADA ANAK YANG MENGALAMI GANGGUAN DI ERA PANDEMI COVID-19 \\ 'Darmin Tuwu, ${ }^{2}$ Bahtiar, ${ }^{3}$ Ratna Supiyah, ${ }^{4}$ Ambo Upe \\ 1,2,3,4 Jurusan Sosiologi Universitas Halu Oleo \\ 1darmintuwu@gmail.com, 2bahtiar_unhalu@yahoo.co.id, 3rtnsupiyah@gmail.com, \\ 4ambo.upe@uho.ac.id \\ Kendari, Indonesia
}

\begin{abstract}
This paper aims to elaborate on the psychosocial support provided by the supervisors and managers of the orphanage to 50 children living in the Social Institution for Children and Adolescents of the Social Service for Southeast Sulawesi Province. This qualitative descriptive study focuses on studying children who experience psychological disorders after undergoing long quarantine during the COVID-19 pandemic. Methods of data collection through observation, in-depth interviews, and Focus Group Discussion. The results of the study show that: First, 50 children have undergone self-quarantine for months in the home. Due to longterm quarantine, the children experience mental and social (psychosocial) disorders in the form of boredom, boredom, and stress. Second, the causes of psychosocial disorders in children are not only caused by the length of quarantine in the orphanage, the prohibition on going to school and the prohibition on visiting other important public places due to the implementation of social distancing and stay at home policies, as well as the difficulty of children understanding the subject matter. online while undergoing online learning at home. Finally, providing psychosocial support to children in difficult times like now is very necessary, considering that the closest people to the child (parents, supervisors, and institution managers) are people who know exactly about the problems and solutions faced by children for healing mental health, social, and child psychology.
\end{abstract}

Keywords: COVID-19; Child psychosocial support; Stress

\begin{abstract}
Abstrak
Tulisan ini bertujuan untuk mengelaborasi bagaimana dukungan psikososial yang diberikan oleh pembina dan pengelola panti kepada 50 orang anak yang tinggal di Panti Sosial Anak dan Remaja Dinas Sosial Provinsi Sulawesi Tenggara. Penelitian deskriptif kualitatif ini menfokuskan kajian pada anak yang mengalami gangguan psikologis setelah menjalani karantina lama di masa pandemic COVID-19. Metode pengumpulan data melalui observasi, wawancara mendalam, dan Focus Group Discussion. Hasil studi menunjukkan bahwa: Pertama, 50 orang anak telah menjalani karanina mandiri selama berbulan-bulan di panti. Akibat karantina dalam jangka waktu lama, anak-anak mengalami gangguan kejiwaan dan sosial (psikososial) berupa rasa bosan, rasa jenuh, dan perasaan tertekan (stress). Kedua, penyebab gangguan psikososial pada anak disamping disebabkan oleh karena lamanya dikarantina di panti, larangan pergi ke sekolah dan larangan mengunjungi tempat-tempat penting publik lainnya akibat penerapan kebijakan social distancing dan stay at home, juga karena disebabkan oleh sulitnya anak-anak memahami materi pelajaran daring selama menjalani pembelajaran secara online di rumah. Terakhir, pemberian dukungan psikososial pada anak di masa-masa sulit seperti sekarang sangat diperlukan, mengingat orang-orang terdekat anak tersebut (orang tua, pembina, dan pengelola panti) merupakan orang yang tahu persis perihal masalah dan solus yang dihadapii anak untuk penyembuhan kesehatan mental, sosial, dan kejiwaan anak.
\end{abstract}

Kata Kunci: COVID-19; Dukungan psikososial anak; Stres

Open Access at: $h$ htp://ojs.uho.ac.id/index.php/PUBLICUHO/index

Journal Publicuho is licensed under a Creative Commons Attribution 4.0 International License. 


\section{Journal Publicuho}

ISSN 2621-1351 (online), ISSN 2685-0729 (print)

\section{PENDAHULUAN}

Anak merupakan generasi penentu kehidupan suatu bangsa di masa mendatang. Pasal 1 butir 1 Undang-Undang Nomor 23 Tahun 2002 tentang Perlindungan Anak menyatakan bahwa: "anak adalah seseorang yang belum berusia delapan belas tahun, termasuk anak yang masih dalam kandungan". Anak adalah buah cinta yang sudah seharusnya mendapatkan kasih sayang, perlindungan, dan dukungan dari orang tua serta orang-orang di sekitarnya. Masa kecil anak seharusnya diisi dengan bermain, keceriaan, kegembiraan, dan gelak tawa riang dari sang anak. Namun tidak semua anak menikmati masa bahagia tersebut, disebabkan oleh kondisi dan masalah-masalah yang dihadapi oleh anak (Aas, 2004). Masalah-masalah umum yang kerap dihadapi oleh anak antara lain adalah: eksploitasi anak secara ekonomi, kenakalan remaja (Nikmah, 2016), anak yang diperdagangkan, pelecehan seksual pada anak (Sunarni dkk., 2020;) anak dengan korban/penyalahgunaan narkotika (Tuwu, 2019), anak korban kekerasan fisik dan mental (Diyah, 2016; Sukiman, 2017; Tuwu, 2018; Khaerul, 2019), anak penyandang cacat serta anak korban penelantaran.

Masalah anak yang mengalami kekerasan seksual bukan hanya masalah fisik, tetapi juga masalah psikologis dan sosial yang akan ditanggungnya seumur hidup (Carson, Foster, \& Chowdhury, 2014). Masalah psikososial yang dialami anak korban kekerasan seksual juga ikut dirasakan oleh keluarga yang anaknya mengalami kekerasan seksual (Hernandez et al., 2009). Kondisi seperti ini dapat menimbulkan beban bagi keluarga yang tidak ringan dan dapat menyebabkan keluarga mengalami krisis psikologis. Fontaine (2009) menyatakan bahwa beban psikologis seperti ini dapat menyebabkan keluarga mengalami stres emosional sebagaimana bentuk respon keluarga terhadap perasaan duka dan trauma.

Anak-anak yang mengalami gangguan psikososial, harus mendapat perlindungan dan dukungan penyembuhan dari orang tua, orang dewasa, dan lingkungan sosialnya. Bentuk dukungan yang diberikan kepada anak korban kekerasan seksual yaitu dalam bentuk dukungan psikososial dimana dukungan ini diharapkan mampu mengatasi masalah psikososial yang ditimbulkan dari kejadian kekerasan seksual pada anak (Kemenkes RI, 2019).

Unit Pelaksanan Teknis Daerah (UPTD) Panti Sosial Anak dan Remaja (PSAR) Dinas Sosial Provinsi Sulawesi Tenggara, merupakan salah satu lembaga pemerintah yang menyelenggarakan kegiatan pembinaan, pendidikan, dan keterampilan kepada anak dan remaja yang putus sekolah dan/atau belum bekerja. Sejak zaman orde baru tahun 1980-an sampai sekarang telah melakukan pembinaan pada anak dan remaja dengan menggunakan sistem rekrutmen. Tahun 2020 UPTD-PSAR membina 50 orang anak usia 10-18 tahun, diutamakan anak yang putus sekolah mulai dari kelas 4 SD sampai tamat SMA. Latar belakang anak yang masuk dalam panti umumnya adalah anak yatim piatu, anak terlantar, 
anak yang berasal dari keluarga berantakan (broken home), dan anak yang tidak mampu secara ekonomi (anak yang berasal dari keluarga miskin).

Pada masa pandemic COVID-19, mulai periode bulan Maret sampai akhir bulan Agustus 2020, anak-anak menjalani masa karantina dan berdiam diri dalam lingkungan asrama sebagai dampak dari implementasi kebijakan pemerintah seperti: social distancing, stay at home, study from home, study via online dan lain-lain (Tuwu, 2020). Selama masa pandemic, pemerintah menerapkan kebijakan pembatasan interaksi fisik (social distancing) untuk memperlambat penyebaran COVID-19, melalui Intervensi: karantina bagi orang-orang yang diduga terinfeksi, pembatasan perjalanan domestik dan internasional, larangan berkumpul dalam kelompok dan keramaian, serta penutupan sekolah, pabrik, restoran, dan ruang publik.

Setelah pandemic COVID-19 menjadi bencana non-alam (Keppres Nomor 12 Tahun 2020), persoalan anak menjadi kompleks disebabkan oleh penerapan Undang-Undang Nomor 6 Tahun 2018 Tentang Kekarantinaan Kesehatan dan implementasi kebijakan pemerintah seperti "stay at home" dan "study from home" yang merubah pola kebiasaan anak seperti sebelum pandemi anak-anak bisa belajar di sekolah secara bertatap muka langsung dengan gurunya, bertemu teman, bermain, mengunjungi tempat-tempat penting, dan mengerjakan berbagai kegiatan lainnya. Namun setelah pandemi melanda Indonesia, semua aktivitas sekolah dan kegiatan bertemu orang banyak di tempat ramai menjadi dilarang oleh pemerintah. Anak tidak boleh bertemu dengan orang banyak dan tidak boleh keluar rumah tanpa menggunakan masker. Kebijakan pemerintah ini membawa masalah tersendiri bagi anak utamanya mereka yang tidak bisa beradaptasi dengan perubahan. Karantina, isolasi, dan stay at home serta belajar online membuat anak bosan, jenuh, dan bahkan stress (Abdullah, 2020) yang disebabkan oleh mereka terlalu lama tinggal di asrama. Kondisi stress pada anak-anak dalam jangka panjang akan berdampak buruk pada kesehatan psikologis dan sosial anak, serta menjadi rentan terjangkiti virus.

Sejauh ini belum banyak penelitian yang mengukur pengaruh bencana, wabah terhadap kesehatan jiwa dan psikososial anak, namun berdasarkan hasil penelitian WHO (2005) saat bencana tsunami, menemukan perlu segera dilakukan promosi kesehatan jiwa dan psikososial, pencegahan terjadinya masalah kesehatan jiwa dan psikososial, serta mendeteksi dan memulihkan masalah kesehatan jiwa dan psikososial (Fahrudin, 2018). Stres dapat mempengaruhi perilaku, mental, dan aktivitas psikososial anak. Mengingat adanya risiko peningkatan masalah sosial dan gangguan kejiwaan akibat COVID-19 pada anak. Tulisan ini bertujuan untuk mengeksplorasi tentang pemberian dukungan psikososial pada anak yang mengalami gangguan psikososial akibat wabah COVID-19 di UPTD-PSAR Dinas Sosial Provinsi Sulawesi Tenggara. 


\section{Journal Publicuho}

ISSN 2621-1351 (online), ISSN 2685-0729 (print)

\section{METODOLOGI}

Penelitian kualitatif yang menggunakan pendekatan studi kasus (Yin, 2008)ini telah dilaksanakan di Unit Pelaksanan Teknis Daerah (UPTD) Panti Sosial Anak dan Remaja (PSAR) Dinas Sosial Provinsi Sulawesi Tenggara, yang beralamat di Jalan Mayjend DI Panjaitan Nomor 222 Kendari.

Obyek penelitian adalah 50 orang anak yang tinggal di Panti dan mempunyai gangguan akibat wabah corona. Teknik penentuan informan secara purposive dan snowball sampling (Sugiyono, 2007). Metode pengumpulan data berdasarkan observasi partisipan, wawancara mendalam, dan focus group discussion.

Teknik analisis data dilakukan melalui proses pengumpulan data, penyajian data, reduksi data, interpretasi, dan penarikan kesimpulan, dari awal penelitian hingga akhir penelitian untuk menjawab tujuan penelitian.

\section{HASIL DAN PEMBAHASAN}

\section{Kondisi Eksisting anak PSAR di Era Pandemi COVID-19}

Sebagai calon pemimpin, anak merupakan tumpuan harapan bangsa di masa depan. Meski menyimpan segudang harapan yang menjanjikan, namun anak juga menyimpan masalah-masalah kompleks dalam dirinya. Misalnya dari sisi perkembangan fisik dan psikologis anak belum matang sehingga masih membutuhkan pemeliharaan, perawatan, cinta, kasih sayang, perhatian, pendidikan, dan dukungan untuk menunjang perkembangannya. Masa anak-anak ditandai dengan perkembangan fisik, sosial, dan mental-psikologis, dengan keadaan tubuh yang terus mengalami perubahan, sehingga tidak jarang muncul berbagai masalah dalam diri anak. Dalam masa perkembangan fisik dan psikologis tersebut, keadaan kejiwaan anak cenderung bersifat tidak stabil (labil), gampang meniru perilaku-negatif tanpa seleksi yang ketat, mudah terprovokasi dengan isuisu negative, serta mudah mengikuti ajakan teman, meskipun ajakan tersebut belum tentu baik untuk dirinya, bahkan tidak jarang karena ketidak tahuan anak sering terjebak dalam masalah.

Gangguan dan masalah yang sering kali menimpa anak pada umumnya sangat beragam, baik dilihat dari sisi anak sebagai pelaku maupun anak sebagai korban, mulai dari persoalan ekonomi, agama, sosial, psikologi, budaya, politik, pendidikan, kesehatan, kekerasan, dan lain-lain. Sebagai contoh masalah anak misalnya masalah-masalah yang berkaitan dengan keadaan fisik, psikis, sosial, serta kesulitan belajar; pelecehan seksual, kekerasan dan perilaku destruktif lain dari anak, seperti tawuran, geng-gengan, minum minuman keras, perilaku seks bebas, pencurian, perkosaan, perampokan, dan lain-lain.

Permasalahan yang dihadapi oleh anak berbeda-beda sesuai dengan kondisi, tingkatan umur, dan tingkatan pendidikan misalnya PAUD, Sekolah Dasar, dan anak remaja 
(tingkat SMP-SMA). Permasalahan yang dihadapi oleh anak usia PAUD misalnya: ngompol, sulit makan, mengamuk, kecemasan di tempat baru, memukul atau menggigit teman, dan kecemasan berpisah dengan orang tua. Permasalahan yang dihadapi oleh anak usia Sekolah Dasar misalnya: malas sekolah, sulit berteman, dihina teman, kesulitan belajar, dan malas membuat Pekerjaan Rumah (PR). Adapun permasalahan yang dihadapi oleh anak usia remaja misalnya: berkelahi antar kelompok (tawuran), menghina teman (bullying), sering berbohong, membuat keributan, gaya hidup konsumtif, terpengaruh minuman keras dan narkoba, merokok, bolos sekolah, pergaulan bebas, serta kecanduan games, media sosial, dan pornografi.

Pada masa pandemic COVID-19, sejak bulan Maret sampai sekarang, anak-anak menjalani karantina di panti. Karantina mandiri (self isolation) merupakan teknik penting untuk membantu melindungi anak dari infeksi virus corona.

Karantina mandiri merupakan cara untuk melindungi diri dari penyakit menular dan menghentikan penyebarannya. Hal-hal yang dilakukan saat melakukan karantina mandiri adalah: tinggal di rumah tidak pergi ke luar rumah, sekolah atau tempat umum tidak menggunakan transportasi umum seperti angkutan kota, ojek, bus, atau taksi kecuali ada pemberitahuan bahwa transportasi yang kita gunakan aman dari virus. Saat dihimbau karantina mandiri, anak harus tinggal di dalam panti dan menghindari kontak dengan orang lain di luar panti. Hal itu bertujuan untuk mencegah penyebaran penyakit ke keluarga, teman, dan masyarakat luas.

Pada waktu melakukan karantina mandiri dalam jangka waktu berbulan-bulan dapat menimbulkan persoalan pada anak. Masalah-masalah yang dihadapi oleh anak di UPTD-PSAR yang umumnya merupakan anak yatim piatu, anak terlantar, anak yang berasal dari keluarga broken home, dan anak yang kurang mampu (miskin) adalah anak-anak merasa jenuh, bosan, stress, bahkan trauma. Hal tersebut sebagaimana dikatakan oleh salah seorang anak di UPTD-PSAR berikut ini. Ketika ditanya dengan pertanyaan: "Sudah berapa lama kamu bersama teman-temanmu dikarantina di dalamPanti sini"? Jawabannya dapat dilihat dari wawancara berikut ini.

"Saya bersama teman-temanku di sini sudah lama tidak bisa pergi atau kami dilarang keluar-keluar atau kami dilarang pergi-pergi pak, termasuk juga tidak bisa lagi pergi ke sekolah karena kami sudah belajar di panti sini pak secara online. Pokoknya sejak akhir bulan Maret atau awal bulan April 2020 pak. Kami merasa bosan, jenuh, dan sempat juga merasa stres, karena kami tinggal terus di sini dan tidak bisa pergi ke mana-mana (Wawancara dengan Fitri, Tanggal 23 Agustus 2020)".

Berdasarkan pada hasil wawancara dengan salah seorang anak yang tinggal di Panti Sosial Anak dan Remaja tersebut, dapat diketahui bahwa anak-anak merasa bosan dan jenuh disebabkan oleh karena mereka sudah terlalu lama tinggal berdiam diri atau tinggal bersama teman-temannya dalam panti (stay at home) dalam waktu yang lama. 


\section{Journal Publicuho}

ISSN 2621-1351 (online), ISSN 2685-0729 (print)

Volume 3 Number 3 (August-October), (2020) pp.394-404

Accredited SINTA SK.NOMOR 28/E/KPT/2019

Open Access at: http://ojs.uho.ac.id/index.php/PUBLICUHO/index

DOI: 10.35817/jpu.v3i3.14489

Sebagai dampak dari penerapan kebijakan pemerintah terkait pemutusan mata rantai penyebaran virus corona, misalnya kebijakan menjaga jarak (physical distancing), kebijakan tinggal di rumah (stay at home), kebijakan belajar dari rumah (study from home) karena semua sekolah ditutup oleh pemerintah, menyebabkan anak-anak banyak yang merasa bosan dan jenuh. Dari hasil wawancara dan Focus Group Discussion saya bersama anak-anak Panti, hampir semua mereka memberikan jawaban yang sama yaitu anak-anak merasa bosan dan jenuh. Oleh karena itu perlu upaya dan dukungan dari berbagai pihak untuk memulihkan kondisi anak seperti sedia kala, sehingga keadaan psikososial mereka tidak terganggu dan pulih kembali.

Untuk mengetahui bagaimana keadaan psikologi dan sosial (psikososial) anak yang tinggal (stay at Cottage) di dalam panti selama berbulan-bulan lamanya, karantina selama masa pandemic COVID-19, dapat disimak dalam wawancara dengan salah seorang anak berikut ini.

"Bagaimana perasaanmu dek selama menjalani masa karantina atau tinggal dalam Panti selama berbulan-bulan tepatnya bulan Maret 2020 sampai bulan September 2020. Apa yang kamu rasakan dek? Eeh anu pak, saya bersama teman-temanku di sini merasa bosan, dan jenuh. Soalnya kami tinggal terus di sini pak, capek, kami tidak boleh keluar panti karena dilarang sama Bapak Pengasuh kami. Kami juga tidak bisa pergi ke sekolah karena sudah ada larangan pergi ke sekolah. Jadi kami sekarang belajar dan sekolah mi juga di sini pak. Belajar online. Tapi parahnya, ada teman saya yang sempat stress karena tertekan jiwa dan perasaannya. Yang membuat teman saya stress karena tidak bisa keluar panti dan stress karena tidak mengerti pelajaran melalui online (Wawancara dengan Nandar Tanggal 24 Agustus 2020)".

Perihal gangguan atau sumber masalah yang membuat anak merasa bosan dan jenuh dapat diketahui dari wawancara dengan salah satu informan berikut di bawah ini.

"Apa hal yang membuat kamu merasa bosan dan jenuh, selama menjalani masa karantina atau "stay at home" dan "study from home"? Yang membuat saya bosan itu pak adalah terlalu lama kami tinggal di dalam panti, dan kami tidak bisa pergi sekolah, pergi ke rumah teman, dan lain-lain (Wawancara dengan Dewiyanti Tanggal 25 Agustus 2020)".

Perihal gangguan atau sumber masalah yang membuat anak merasa tertekan (stress) perasaan dan kejiwannya dapat diketahui dari wawancara dengan salah satu informan berikut di bawah ini.

"Apa hal yang membuat kamu dan teman-temanmu merasa tertekan jiwa dan perasaanmu (stress), selama menjalani masa karantina di panti atau "stay at home" dan "study from home" dalam enam bulan terakhir? Yang membuat saya dan teman-teman di sini stres itu pak adalah belajar secara online pak. Jujur kami mengalami kesulitan dalam memahami materi pelajaran dari guru kami. Mata pelajaran yang paling membuat saya jengkel dan stress adalah pelajaran matematika pak. Dulu, kalau masih belajar di sekolah pak, kalau saya tidak mengerti dengan materi pelajaran, saya bisa angkat tangan untuk bertanya sama guru supaya menjelaskan ulang materi pelajarannya. Tapi sekarang, belajar di panti di masa pandemi dengan sistem online, saya merasa kesulitan paham. Belum lagi 
masalah jaringan yang tidak stabil atau putus-putus (Wawancara dengan Hendriwan Tanggal 26 Agustus 2020)".

Mengingat banyaknya persoalan yang bakal menerpa anak, seyogyanya anak perlu mendapat perhatian, perlindungan, dan dukungan dari keluarga dan orang-orang terdekat di lingkungan sosialnya, untuk menyelesaikan persoalan-persoalan yang menimpa anak, agar anak dapat tumbuh dan berkembang dengan baik hingga dia menjadi matang dan dewasa. Diantara dukungan yang dapat diberikan untuk mengatasi permasalahan pada anak misalnya: menemani anak, menghargai anak (respect), penerapan aturan (rules), menjadi contoh bagi anak (role models), memberi dukungan pada anak, sediakan waktu untuk anak, awasi kegiatan belajar di rumah, mengajarkan tanggung jawab, menjadi teman terbaik, disiplin menjaga kesehatan anak, dan lain-lain.

\section{Pemberian Dukungan Psikososial kepada anak Yang Mengalami Gangguan di Era Pandemi Covid-19}

Anak merupakan salah satu kelompok rentan yang mudah mendapat masalah, gangguan dan/atau tertular oleh virus corona, karena itu mereka harus dilindungi dan didukung. Kelompok rentan mesti mendapat perlakuan khusus untuk promosi, pencegahan, pemulihan dan rehabilitasi masalah gangguan kesehatan jiwa dan psikososial.

Anak yang mengalami gangguan mental dan gangguan kejiwaan seperti bosan, jenuh, dan gampang stress, harus mendapat perhatian dan dukungan psikososial dari berbagai pihak utamanya orang-orang terdekat seperti anak pengasuh atau orang tua. Psikososial adalah relasi yang dinamis antara aspek psikologis dan sosial seseorang. Sementara dukungan psikososial adalah segala bentuk dukungan dari lokal maupun pihak luar yang bertujuan untuk menjaga atau mempromosikan kesejahteraan psikososial dan/atau mencegah atau mengatasi gangguan jiwa. Dukungan psikososial dipakai untuk merespons kondisi kedaruratan maupun bencana, salah satunya pandemic COVID-19, yang mengintegrasikan pendekatan biologis, psikologis, dan sosiokultural di bidang kesehatan, sosial, pendidikan dan komunitas, serta untuk menekankan perlunya pendekatanpendekatan yang beragam dan saling melengkapi dari berbagai profesi dalam memberikan dukungan yang sesuai.

Peristiwa Pandemi COVID-19 menghentikan hampir semua aktivitas anak dan remaja di luar rumah seperti sekolah dan larangan untuk berkumpul dengan teman sebaya tanpa menjaga jarak sosial. Jadi anak merasa stres/tertekan, cemas dan bosan di Panti terus menerus yang terkadang diekspresikan melalui emosi dan perilakunya. Orang tua, pengasuh, dan pengelola PSAR sebaiknya peka terhadap kebutuhan anak yang memerlukan dukungan kesehatan jiwa dan psikososial ketika merasa stres, sedih, marah, cemas dan bosan.

Dukungan yang diberikan pada anak harus memperhatikan hal-hal sebagai berikut: 


\section{Journal Publicuho}

ISSN 2621-1351 (online), ISSN 2685-0729 (print)

Pertama, untuk kesehatan fisik pada anak dan remaja diberikan kegiatan positif dengan pemberian penjelasan agar anak tidak kontak atau menjaga jarak dengan orang lain (social distancing), serta tidak menakut-nakuti anak dengan informasi negative yang dapat merusak dan mengganggu kesehatan jiwanya. Orang tua (Pembina) juga dapat memberikan contoh terkait pola hidup bersih dan sehat dengan beristirahat yang cukup, berolahraga teratur, makan dengan nilai gizi seimbang, rajin mencuci tangan dan tetap bersosialisasi dengan teman dan anggota keluarga melalui media sosial.

Kedua, untuk kesehatan jiwa dan psikososial pada anak dan remaja, Pembina (orang tua) perlu mengelola dengan baik stres dan emosi yang dialami anak, bersikap tenang dan dapat lebih mendekatkan hubungan dengan anak. Sikap orang tua dalam menanggapi masa pandemi COVID-19 dapat mempengaruhi kondisi kejiwaan dan psikososial anak, karena orang tua berperan penting bagi kehidupannya.

Cara orang tua dan pengasuh dalam mengatasi gangguan, emosi dan mengelola gangguan dan stres pada anak antara lain dapat dilakukan dengan berikut ini:

Tabel 1. Dukungan Psikososial Pada Anak Yang Mengalami Gangguan

No Jenis dukungan Psikososial pada anak yang mengalami gangguan

1 Ajak anak berbicara dengan tenang dan penuh kasih sayang, beri kesempatan mengekspresikan perasaan dan mengungkapkan isi pikiran, serta memberikan rasa aman;

2 Berikan pujian dan motivasi pada anak terkait aktivitas yang dilakukan:

3 Fasilitasi interaksi anak dengan teman-temannya melalui media sosial;

4 Bantu melakukan kegiatan yang disukai (hobi) atau yang dapat membuat ketenangan, menarik dan menyenangkan seperti cara mencuci tangan dan menggunakan masker dengan benar, meng-gambar, menyanyi karaoke, masak bersama atau mengajak mereka berjalan-jalan di sekitar rumah yang disesuaikan dengan usia dan kemampuan anak;

5 Hindari segala bentuk kekerasan secara fisik, psikologis dan sosial. Membentak atau kekerasan terhadap anak hanya akan menambah rasa stress dan marah, pada diri orang tua maupun anak;

6 Tetap mengawasi penggunaan media sosial terutama informasi tentang COVID-19 yang dapat menimbulkan kecemasan berkepanjangan.

7 Melakukan kegiatan relaksasi atau peregangan dengan menarik nafas dalam, tahan dan hembuskan melalui mulut secara perlahan setiap merasa cemas atau tertekan;

8 Melakukan olah raga sesuai kondisi di sekitar panti.

9 Membuat jadwal kegiatan harian untuk belajar dan bersantai atau menyenangkan yang dapat dilakukan secara rutin.

10 Kenali tanda-tanda masalah kejiwaan dan psikososial seperti : gelisah, sedih, bosan, mudah tersinggung, agresif, menyendiri. Jika diketemukan segera cari pertolongan pada tim kesehatan yang terdekat. Sumber: Data Diolah, 2020. 


\section{KESIMPULAN}

Pandemi COVID-19 telah merubah segalanya termasuk merubah budaya dan kebiasaan hidup orang dewasa dan anak-anak. Pandemi menghentikan hampir semua aktivitas anak di luar rumah seperti kegiatan sekolah dan larangan untuk bermain dan berkumpul dengan teman sebaya tanpa menjaga jarak sosial. Akibatnya anak merasa cemas, bosan, dan bahkan tertekan (stres) yang diekspresikan melalui emosi karena mereka terus menerus tinggal di Panti. Menyikapi hal tersebut, orang tua, pengasuh, dan pengelola Panti Sosial Anak dan Remaja seyogyanya peka terhadap kebutuhan dan masalah anak yang memerlukan dukungan kesehatan jiwa dan psikososial ketika mereka merasa stres, sedih, marah, cemas dan bosan.

Dukungan yang dapat diberikan orang tua, pembina anak, dan pengelola panti kepada anak adalah sebagai berikut: Pertama, untuk hal yang terkait dengan kesehatan fisik anak dan remaja diberikan kegiatan positif, menjaga jarak dengan orang lain (social distancing), tidak menakut-nakuti anak dengan informasi negatif yang dapat mengganggu kesehatan jiwanya. Pembina juga dapat memberikan contoh terkait pola hidup bersih dan sehat dengan beristirahat yang cukup, berolahraga secara teratur, makan dengan nilai gizi seimbang, rajin mencuci tangan dan tetap bersosialisasi dengan teman dan anggota keluarga melalui media sosial.

Kedua, untuk kesehatan jiwa dan psikososial anak dan remaja, pembina dan pengelola panti perlu mengelola dengan baik persoalan yang dihadapi anak berupa gangguan psikologis seperti rasa cemas, rasa bosan, rasa jenuh, stres serta emosi yang meningkat yang dialami anak.

Terakhir, pembina dan pengelola panti seyogyanya dapat lebih mendekatkan hubungan sosial (intimate relation) dengan anak, agar dapat mengetahui secara lebih dekat dan mendalam masalah apa yang sedang dihadapi anak. Dengan begitu persoalan anak dapat diselesaikan, sehingga dapat tercipta suasana batin dan psikologis anak yang sehat, aman, nyaman, dan bahagia. 


\section{Journal Publicuho}

ISSN 2621-1351 (online), ISSN 2685-0729 (print)

\section{DAFTAR PUSTAKA}

Aas Saomah, (2004). Permasalahan Anak dan Upaya Penanganannya, Jurusan

Psikologi Pendidikan dan Bimbingan Fakultas IImu Pendidikan Universitas Pendidikan Indonesia.

Abdullah, I. (2020). Psychological Trauma: Theory, Research, Practice, and Policy

COVID-19: Threat and Fear in Indonesia.

https://doi.org/http://dx.doi.org/10.1037/tra0000878.

Brammer. L. M., Abrego, P. J., \& Shostrom, E. L. (1993). Therapeutic counseling and

psychotherapy. Sixth Ed. Englewood Cliffs, New Jersey: Prentice Hall.

Carson, D. K., Foster, J. M., \& Chowdhury, A. (2014). Sexual abuse of children and youth in india: An anthropological perspective. The Oriental Anthropologist, $14(2), 343-364$.

Diyah \& Ali Imron (2016). Kekerasan Dalam Pendidikan (Studi Fenomenologi Perilaku Kekerasan Di Panti Rehabilitasi Sosial Anak). Jurnal Paradigma Volume 04 Nomor 03 Tahun 2016.

Fahrudin, Adi, (2018). Perspektif Biopsikososial Untuk Asesmen Keberfungsian Sosial. (Bandung: PT. Refika Aditama).

Fontaine. K.L. (2009). Mental health nursing. New Jersey: Pearson Education Inc.

Hernandez, A., et al. (2009). An Integrated Approach to Treating Non-Offending Parents Affected by Sexual Abuse. Social Work in Mental Health, 7(6), 533-555.

https://nasional.kompas.com/read/2020/07/31/16053271/update-31-juli-ada-60739-

kasus-suspek-terkait-covid-19-di-indonesia diakses tanggal 31 Juli 2020 pukul 20.57 wita.

Kementerian Kesehatan RI. 2019. Pedoman Pencegahan dan Pengendalian Coronavirus Disease (COVID-2019).

Kementerian Pemberdayaan Perempuan dan Perlindungan Anak Republik Indonesia (2020). Buku Panduan Dukungan Psikososial Bagi Anak Korban Bencana Alam.

Keputusan Presiden (KEPPRES) No. 12 Tahun 2020 tentang Penetapan Bencana Nonalam.

Khaerul Umam Noer, (2019). Mencegah Tindak Kekerasan pada Anak di Lembaga Pendidikan. (SAWWA - Jurnal Studi Gender Volume 14, Nomor 1, 2019) hal 4766. 
Mannarino, A. P., Cohen, J. A., Deblinger, E., \& Steer, R. (2007). Self-Reported Depression in Mothers of Children Who Have Experienced Sexual Abuse. Journal of Psychopathology and Behavioral Assessment, 29, 203-210.

Nikmah Rahmawati, (2016). Kenakalan Remaja dan Kedisiplinan: Perspektif Psikologi dan Islam. Jurnal SAWWA - Volume 11, Nomor 2, April 2016, hal 267.

Republik Indonesia, Undang-Undang Nomor 23 Tahun 2002 Tentang Perlindungan Anak.

Republik Indonesia, Undang-undang Nomor 6 Tahun 2018 Tentang Kekarantinaan Kesehatan.

Sugiyono. (2007). Metode Penelitian Kuantitatif Kualitatif Dan R \& D. Penerbit Alfabeta.

Sukiman, (2017). Seri Pendidikan Orang Tua: Mendampingi Anak Ketika Bermasalah. (Jakarta: Kementerian Pendidikan dan Kebudayaan, 2017) hal 2-5.

Sunarni, dkk., Pelaku Pelecehan Seksual dan Proses Pembinannya: Studi di Lembaga Pembinaan Khusus Anak Kelas II Kota Kendari. Jurnal kesejahteraan dan Pelayanan Sosial Vol 1 Nomor 1 Mei (2020) hal 29-42.

Tuwu, Darmin (2019). Penanggulangan Peredaran Narkoba Dan Kinerja Pegawai Badan Narkotika Nasional Sulawesi Tenggara. Al Izzah: Jurnal Hasil-Hasil Penelitian Volume 14, Nomor 1 (Mei, 2019) pp 74-90.

Tuwu, Darmin (2020). Kebijakan Pemerintah Dalam Penanganan Pandemi COVID-19. Jurnal Publicuho Volume 3 Number 2 (May-July), (2020) pp.267 -278.

Tuwu, Darmin, (2018). Konflik, Kekerasan, dan Perdamaian. Kendari: Literacy Institute. Undang-Undang Nomor 23 Tahun 2002 Tentang Perlindungan Anak.

WHO (2005). Briefing Note on Psychosocial/Mental Health Assistance to the TsunamiAffected Region. WHO: Departement of Mental Health and Substance Abuse.

WHO. 2020. Mental health and psychosocial considerations during the COVID-19 outbreak.

Yin, R. K. (2008). Case Study: Design and Method. PT. RajaGrafindo Persada. 